Collection: NFZ Summer School 2009 - Birmensdorf (Switzerland)

Long-term ecosystem research: understanding the present to shape the future Guest Editor: Marcus Schaub (WSL, Switzerland)

\title{
Indicators of drought effects in Pinus sylvestris: genetic analyses to corroborate the results of empirical methods
}

\author{
Lechner RAB ${ }^{(1)}$, Rigal A ${ }^{(2)}$ \\ Drought periods can be responsible for substantial damage in forests. Different \\ studies have used empirical methods to measure the impact of drought on \\ trees. More recently, huge advances in genomics have allowed finding poten- \\ tial genetic markers involved in drought resistance or tolerance. In this paper \\ we review some empirical and genomic approaches that have been published \\ in the literature. We suggest that a combination of these two types of ap- \\ proaches allows a better understanding of the mechanisms leading to drought \\ resistance or tolerance.
}

Keywords: Drought, Pinus sylvestris, Resistance, Genetic markers

\section{Introduction}

Several studies on climate predict that extreme weather events like high temperatures and continuous droughts will occur more of ten in the future (Klein Tank \& Können 2003). These phenomena represent a concrete risk for forest integrity. Drought events will strongly affect plant communities in forests (Schaub 2009). The most visible effects that correlate with drought are crown transparency, dead branches, mistletoe and fungus infection (Dobbertin \& Rigling 2006). For example, several studies on a site near Visp (Switzerland) have shown that annual tree mortality could be correlated with drought periods (Bigler et al. 2006). Statistical analyses indicate that more than 59\% of the Scots Pines (Pinus sylvestris) at the Visp site have died since 1996 (Dobbertin \& Rigling 2006). However, some trees belon-

(1) Limnologische Station, Technische Universität München, Hofmark 1-3, D-82393 Iffeldorf (Germany); (2) UMR INRA/UHP 1136 "Interaction Arbres/Micro-organismes", INRA Nancy, F-54280 Champenoux (France)

@ Lechner Robert (lechner-robert@web.de) Received: May 25, 2010 - Accepted: May 31, 2010

Citation: Lechner RAB, Rigal A, 2010. Indicators of drought effects in Pinus sylvestris: genetic analyses to corroborate the results of empirical methods. iForest 3 : 89-91 [online: 2010-07-15] URL:

http://www.sisef.it/iforest/show.php? id $=539$ ging to the same population have adapted to drought and become more resistant to pathogens and parasite agents.

In this review, we introduce several empirical methodologies currently used to measure the impact of drought on Scots Pine. In particular, measures of the crown transparency, productivity (e.g., radial growth, height increment, and needle length), sap fluxes, and lifespan will be presented and discussed. In addition to these, we will focus on some genetic approaches that have recently been used to investigate the presence of genetic markers that may be involved in drought resistance and how discuss they can improve the results of the empirical methods.

\section{Methods}

Several empirical methods have been used to measure the impact of drought on trees.

\section{Crown transparency}

The vitality of the trees can be measured by comparing the crown transparency. To obtain coherent results, a stationary automatic camera takes a series of pictures. The background in these pictures should be neutral. The crown transparency can be evaluated by measuring the amount of green colour in each picture (Dobbertin \& Rigling 2006).

\section{Growth of the trunk/stem}

Another way is to compare the productivity of the trees by measuring the radial growth of the tree trunk or the height increment. These precise methods can be easily reproduced, especially if the measured points are exactly defined (Dobbertin 2005)

\section{Compensation Heat Pulse Method}

Another method of assessing of the tree vitality is to measure the water transport in the xylem by using the Compensation Heat Pulse Method (CHPM). This involves determining water transport in the xylem tissue through the propagation of short heat pulses (Green et al. 2003).

\section{Needle vitality}

The healthiness of a conifer tree is also reflected in the vitality of its needles. Good indicators are the speed of growth, the needles final length and lifespan. The speed of growth and needles final length are determined by proximal and distal measurements of the bases of the shoots of branches. These results can also be correlated with climatic measurements (Dobbertin et al. 2009).

\section{Needle Trace Method}

The Needle Trace Method (NTM) is another method to evaluate the lifespan and the needle loss. It is based on the knowledge that the supply channel of a needle is visible in the timber. The canal goes through the different tree rings, ending on a particular annual ring, which marks the end of the life of that needle. The life span of needles can be measured by counting the number of annual rings in which the supply channel is visible. The advantage of this method is that it is possible to trace back needle vitality for about 400 years (Jalkanen et al. 2009).

In addition to these empirical approaches, the field of genetics can possibly contribute to our understanding of why some trees are more resistant to drought than others. The general aim is the search of genetic markers involved in drought resistance. More studies have been performed to try to find the genetic markers related to drought response.

The RAPD (Random Amplified Polymorphic DNA) markers have already been used by Fournier et al. (2006) to characterize two tree populations, one showing the impact of drought and the other one being in good physical conditions (Fournier et al. 2006). Fournier et al. (2006) generated a partial comparative profile of the genome of the two tree populations. Because it was impossible to cover all the genome sequences, the probability of finding the markers involved in drought resistance was very low.

However, recently huge progress in lab methodologies has recently been achieved and produced enormous amounts of genomic and sequence data which can be analyzed and interpreted. This has allowed recent advances on the identification of drought-related genes.

For example, Watkinson et al. (2003) worked on the pattern of gene regulation between trees exposed to mild or severe 
drought stress using microarrays. They highlighted that drought stress caused a variation in regulation of several genes.

Gonzalez-Martinez et al. (2006) worked on the polymorphism pattern of 18 candidate genes for drought-stress response in Pinus taeda. They identified 196 SNPs (Single Nucleotide Polymorphism) from these 18 genes.

Eveno et al. (2008) also used SNP methods coupled with statistics and bioinformatics analysis on Pinus pinaster to confirm the involvement of several genes in drought tolerance. They found five genes that could be candidate that are linked with drought stress response (Eveno et al. 2008).

\section{Discussion}

The interpretation of the collected data with empirical methods is often not clear. Too many unknown factors can influence the results, especially if it is a field trial. A big influence for example can have the presence of many mycorrhiza fungi or different soil composition on the growth rate and the drought-tolerance of trees (Egli \& Brunner 2005). Genetic factors are also an issue, why some trees are more resistant to drought than others. In this way genetics is a possibility to explain the variations and to improve the interpretation. Combined with empirical methods it can lead to better results.

Many genetic methods are used for research on genetic markers. One of the most powerful methods among the genetic approaches is based on using so-called mini-satellites to screen for several gene candidates. Mini-satellites were discovered in 1985 by Jeffreys et al. (1985) and can be detected in various ways, e.g., using microsatellites and AFLP techniques, as explained below.

Mini-satellites with a repetitive sequences maximum of four base pairs in length are known as microsatellites (Simple Sequence Repeats). These SSRs are the basis of the SSLP (Simple Sequence Length Polymorphism) and as a result also of the microsatellite analysis. In this method, microsatellites up to 10 kilobases are selectively multiplied by using the PCR. This is accomplished by using primers, whose sequence is complementary to the flanking areas of the SSRs to analyse the total DNA of the repetitive sequence (Jeffreys et al. 1988).

It is a very reliable method that only investigates polymorphic fragments. It is neither complicated nor time consuming to implement, which makes it suitable especially for extensive studies (Russell et al. 1997). However, one limitation is that the sequence of the flanking DNA segments of the microsatellites must be known.

The analysis of mini-satellites using the AFLP (Amplified Fragment Length Polymorphism) is still a relatively new techno- logy, first developed by Zabeau \& Vos (1993). The method is based on the selective amplification of specific restriction fragments obtained from the digestion of the entire genome. The primers used are marked with fluorescent dyes, then electrophoretically separated according to length and finally detected.

This method has the disadvantage that the level of polymorphism is only $48.6 \%$. This is offset by the large number of fragments that can be produced in one PCR (Russell et al. 1997). Another advantage is that by using different restriction enzymes and primer combinations, the method can be flexibly varied. It can also be applied without having to know the sequence of the genome.

The drawback of the AFLP method is the potential of misinterpretation of the detected fragments. The fact, that two different individuals have a fragment of identical molecular weight in common, can not be taken as an evidence that these individuals actually possess the same homologous fragment. In most cases, however, it can be assumed that these fragments are homologous (Karp et al. 1996).

In addition to the SNP and RAPD that have been already used, the SSLP and AFLP method can be a good choice for QTL (Quantitative Trait Loci) mapping or diversity studies (Vignal et al. 2002). It is possible to obtain good and quick result on genetic marker potentially involved in drought resistance. The identified genes must be verified and confirmed by SNP method associated with statistic and bioinformatic methods to corroborate the results.

\section{Conclusions}

Currently many studies are being undertaken to better understand why some trees are more drought resistant. The genetic methods can complement traditional methods. Moreover they quickly produce results. However, additional studies are necessary to find the most relevant genetic markers. Such markers should open up many opportunities to better understand drought-related issues in arid zones.

\section{References}

Bigler C, Braker OU, Bugmann H, Dobbertin, Rigling A (2006). Drought as an inciting mortality factor in scots pine stands of the Valais, Switzerland. Ecosystems 9: 330-343 - doi: 10.1007/s10021-005-0126-2

Dobbertin M (2005). Tree growth as indicator of tree vitality and of tree reaction to environmental stress: a review. European Journal of Forest Research 124: 319-333. - doi: 10.1007/s10342-0050085-3

Dobbertin M, Rigling A (2006). Pine mistletoe (Viscum album ssp. austriacum) contributes to Scots pine (Pinus sylvestris) mortality in the Rhone valley of Switzerland. Forest Pathology
36 309-322. [online] URL: http://www.wsl.ch/ forschung/forschungsprojekte/foehrensterben_wa 1lis/publikationen/26_dobbertin_rigling.pdf Dobbertin M, Li M, Giuggiola A, Baltensweiler W, Cherubini P (2009). Seasonal needle growth of European larch in the alpine Engadine valley reveals strong advancement as the result of spring warming. In: Proceedings of the Conference: "Long-term ecosystem research: Understanding the present to shape the future". Zurich (CH) 7-10 Sept 2009. Abstract book, pp. 61.

Egli S, Brunner I (2005). Mykorrhiza - Eine faszinierende Lebensgemeinschaft im Wald. Merkbl. Prax. Eidgenöss. Forsch. anst. Wald Schnee Lansch, pp. 35.

Eveno E, Collada C, Guevara MA, Léger V, Soto A, Diaz L, Léger P, Gonzalez-Martinez SC, Cervera MT, Plomion C, Garnier-Géré PH (2008). Contrasting patterns of selection at Pinus pinaster Ait. drought stress candidate genes as revealed by genetic differentiation analyses. Molecular Biology and Evolution 25 (2): 417-437. doi: 10.1093/molbev/msm272

Fournier N, Rigling A, Dobbertin M, Gugerli F (2006). Faible différentiation génétique, à partir d'amplification aléatoire d'ADN polymorphe (RAPD), entre les types de pin sylvestre (Pinus sylvestris L.) d'altitude et de plaine dans les alpes à climat continental. Annales of Forest Sciences 63: 431-439. - doi: 10.1051/forest:2006023

Gonzalez-Martinez SC, Ersoz E, Brown G R, Wheeler NC, Neale DB (2006). DNA sequence variation and selection of tag single-nucleotide polymorphisms at candidate genes for droughtstress response in Pinus taeda L. Genetics 172: 1915-1926. - doi: 10.1534/genetics.105.047126

Green S, Clothier B, Jardine B (2003). Theory and practical application of heat pulse to measure sap flow. Agrononomy Journal 95: 1371-1379. [online] URL: http://agron.scijournals.org/cgi/content/abstract/95/6/1371

Jalkanen R, Aalto T, Kurkela T (2000). Needle Trace Method. Forestry Studies 34, pp. 75-78. Jalkanen R, Aalto T, Närhi P, Vierelä R (2009). Hundreds of years long dynamics of needle tetention, needle longevity and annual needle loss reveald by the Needle Trace Method. In: Proceedings of the Conference: "Long-term ecosystem research: Understanding the present to shape the future". Zurich (CH) 7-10 Sept 2009. Abstract book, pp. 46.

Jeffreys AJ, Wilson V, Thein SL (1985). Individual-specific fingerprints of human DNA. Nature 316: 76-79. - doi: 10.1038/316076a0

Jeffreys AJ, Wilson V, Neumann R, Keyte J (1988). Amplification of human minisatellites by the polymerase chain reaction: towards DNA fingerprinting of single cells. Nucleic Acids Research 16 (23): 10953 - 10971. [online] URL: http://nar.oxfordjournals.org/cgi/content/abstract/ 16/23/10953

Karp A, Seberg O, Buiatti M (1996). Molecular techniques in the assessment of botanical diversity. Annals of Botany 78: 143-149. - doi: 10.1006/anbo.1996.0106

Klein Tank AMG, Können GP (2003). Trends in 
indices of daily temperature and precipitation extremes in Europe, 1946-99. Journal of Climate 16: 3665-3680. - doi: 10.1175/1520-0442(2003) 016<3665:TIIODT $>2.0$. CO;2

Russell JR, Fuller JD, Macaulay M, Powell W, Hatz BG, Jahoor A, Waugh R (1997). Direct comparison of levels of genetic variation among barley accessions detected by RFLPs, AFLPs, SSRs and RAPDs. Theoretical and Applied Genetics 95: 714-722. - doi: 10.1007/ s001220050617

Schaub M (2009). Future monitoring and research needs for forest ecosystems in a changing en- vironnement: an introduction. iForest 2: 54-55. doi: 10.3832/ifor0488-002

Vignal A, Milan D, San Cristobal M, Eggen A (2002). A review on SNP and other types of molecular markers and their use in animal genetics. Genetics Selection Evolution 34: 275-305. - doi: 10.1186/1297-9686-34-3-275

Vos P, Hogers R, Bleeker M, Reijans M, van de Lee T, Hornes M, Frijters A, Pot J, Peleman J (1995). AFLP: a new technique for DNA fingerprinting. Nucleic Acids Research 23 (21): $4407-$ 4414. - doi: 10.1093/nar/23.21.4407

Watkinson JI, Sioson AA, Vasquez-Robinet C,
Shukla M, Kumar D, Ellis M, Heath LS, Ramakrishnan N, Chevone B, Watson LT, van Zyl L, Egertsdotter U, Sederoff RR, Grene R (2003). Photosynthetic acclimation is reflected in specific patterns of gene expression in droughtstressed loblolly pine. Plant Physiology 133: 1702-1716. - doi: 10.1104/pp.103.026914

Zabeau M, Vos P (1993). Selective restriction fragment amplification: a general methos for DNA fingerprinting. Patenscope, WIPO. - [online] URL: http://www.wipo.int/pctdb/en/wo.jsp? $\mathrm{IA}=\mathrm{EP} 1992002216$ 